\title{
Tat-independent Replication of Human Immunodeficiency Viruses
}

\author{
Leo Luznik, * Günter Kraus, * John Guatelli, *\| Douglas Richman, *¥\| and Flossie Wong-Staal*\$ \\ Departments of *Medicine and ${ }^{\ddagger}$ Pathology, University of California, San Diego, School of Medicine; ${ }^{\S}$ Department of Biology, University \\ of California, San Diego, California 92093; and "San Diego Veterans Affairs Medical Center, San Diego, California 92161
}

\begin{abstract}
The replication of human immunodeficiency retroviruses involves a complex series of events that is regulated at both transcriptional and posttranscriptional levels. The tat gene product is a potent trans-activator of viral transcription and therefore an attractive target for the development of antiviral drugs. Tat-defective HIV-1 proviral DNA clones have been shown previously to be replication defective. In this study, we report that tat-defective HIV-1 and HIV-2 viral DNA transfected into U937 cells can direct efficient viral replication in the presence of transcriptional stimulators such as TNF- $\alpha$ and PMA. In MT- 4 cells, tat-defective HIV-1 can replicate without any stimulation. The viruses recovered from MT- 4 cells remained tat defective defined by their inability to infect $T$ cell lines (e.g., Molt 4/8) although replication could be rescued with cytokines. Limited replication was observed in primary mononuclear cells. Furthermore, we showed that Ro 24-7429, a potent tat antagonist and antiviral compound, failed to suppress HIV-1 replication in TNF- $\alpha$-stimulated $T$ cells. These results have important implications for targeting tat as a therapeutic strategy for AIDS. (J. Clin. Invest. 1995. 95:328-332.) Key words: human immunodeficiency virus $\cdot$ tat $\cdot$ TNF- $\alpha \cdot$ Ro 24-7429 • cytokines
\end{abstract}

\section{Introduction}

Human immunodeficiency viruses contain several regulatory genes, among which tat encodes an early protein that transactivates viral gene expression. The Tat protein binds a cis-acting RNA element (TAR), located downstream of the transcriptional initiation site in the viral long terminal repeat (LTR) (1). The mechanism of tat trans-activation has been suggested to be at the level of increasing transcriptional initiation or elongation $(1,2)$. Previous studies indicated that tat is essential for HIV replication (3-6). Additional regulatory elements responsive to cellular transcription factors are also present in the LTR, e.g., the core promoter elements SP-1 and TATA (7), and enhancer elements, including the nuclear factor KB, (NF-kB) binding site (8) which is required for activation of virus expression in response to external stimulation such as immune activation. For

Address correspondence to Flossie Wong-Staal, University of California, San Diego, Department of Medicine 0665, La Jolla, CA 920930665. Phone: 619-534-7957; FAX: 619-534-7743.

Received for publication 13 April 1994 and in revised form 2 September 1994.

1. Abbreviations used in this paper: CAT, choline-o-acetyl transferase; LTR, long terminal repeat; NF-kB, nuclear factor $\mathbf{k B}$.

The Journal of Clinical Investigation, Inc.

Volume 95, January 1995, 328-332 example, TNF- $\alpha$ and PMA activate HIV expression via the uncoupling of NF-kB from its cytoplasmic inhibitor I-kB (8, 9 ). The inductive effect of TNF- $\alpha$ on HIV expression has been shown in a variety of cell types and its molecular mechanism of action is one of the best examples of functional interactions between HIV and the immune system. TNF- $\alpha$ is of particular interest and relevance because of previous reports of elevated plasma levels of circulating TNF- $\alpha$ in HIV-1 -infected individuals $(10,11)$ and increased TNF- $\alpha$ production de novo by freshly isolated PBMC, circulating monocytes, tissue macrophages, and B lymphocytes $(12,13)$. Therefore, the potential stimulatory role of TNF- $\alpha$ in HIV replication and disease progression warrants further examination.

Because of prior evidence for the essential role of tat in HIV replication in vitro several antiviral strategies have been aimed at inhibiting tat function. It has been shown that Tatsequestering systems such as a TAR decoy RNA can inhibit replication of both HIV-1 and HIV-2 (14). Similarly, the benzodiazepine compound Ro 5-3335 [7-chloro-5-(2pyrryl)-3H-1,4benzodiazepin 2(H)-one] and its derivatives, Ro 24-7429, are potent antiviral drugs first identified by screening for tat inhibition $(15,16)$. Molecular mechanism of action of these two compounds is not completely understood but probably involves cellular factors that cooperate in tat action (17).

Treatment of cells acutely or chronically infected with HIV1 or HIV-2 in the presence of $0.3-1 \mu \mathrm{M}$ of Ro 24-7429 significantly reduced expression of viral RNA and antigen in vitro $(15,16)$. In this study, we showed that the inhibitory effects of the tat antagonist can be overridden by TNF- $\alpha$. Furthermore, tat-defective HIV can replicate in the presence of stimulation by TNF- $\alpha$ and PMA in the U937 cells and without any stimulation in the MT- 4 cells. Our results suggest that the requirement of tat may be bypassed by immune activation and cytokine induction, which are common occurrences in HIV-infected individuals.

\section{Methods}

Cells and infections. T cell lines CEM, Molt-3, MT-2, and MT-4 and the monocytic cell line U937 were maintained in RPMI 1640 (Gibco Laboratories, Grand Island, NY) medium supplemented with $10 \%$ FBS, penicillin $(250 \mathrm{U} / \mathrm{ml})$, and streptomycin $(250 \mu \mathrm{g} / \mathrm{ml})$. The CEM cells were infected overnight at $37^{\circ} \mathrm{C}$ with HIV-1 $1_{\text {MN }}$ and HIV-1 $1_{\text {LAI }}$ virus stocks obtained from acutely infected CEM cells and titered on MT-2 cells. After exposure to virus, cells were washed five times with complete RPMI 1640 medium (Gibco Laboratories), resuspended in $10^{5}$ cells/ $\mathrm{ml}$ in the same medium and followed for $1 \mathrm{wk}$. Infection of Molt- 4 cells with HIV-1 $1_{\mathrm{NL} 4.3}$ tat- $)(5,000 \mathrm{ng}$ of virus supernatant $)$ was performed as described for CEM cells. PMA (Sigma Chemical Co., St. Louis, MO), recombinant human TNF- $\alpha$ and IL-6 (both from Promega Corp., Madison, WI) were used as stimulators. Ro 24-7429 dissolved in DMSO was diluted in medium to designated concentrations and was added after infection to cultures together with TNF- $\alpha$. Fresh PBMC isolated from commercial donor leukocytes by standard Ficoll-Hypaque fractionation were stimulated overnight with $2 \mathrm{U} / \mathrm{ml}$ PHA. Cells were maintained in RPMI medium containing $1 \%$ penicillin-streptomycin, $10 \%$ heat- 
inactivated fetal bovine serum, $2 \mathrm{mM} \mathrm{L}$-glutamine, and $50 \mathrm{U} / \mathrm{ml}$ recombinant IL-2. PBMC $\left(6 \times 10^{6}\right.$ cells $)$ were infected with $50,000 \mathrm{ng}$ of HIV- $1_{\text {NLA.3 }}$ tat- $)$ and HIV-1 $1_{\text {LAI }}$ supernatant as described above. Supernatant was collected at designated time points and used for titration experiments and viral antigen (p24) measurements (Coulter Immunology, Hialeah, FL).

Plasmids, transfections, and choline-o-acetyl transferase (CAT) assays. HIV clones with defective tat gene used in the study were: HIV$1_{\text {HXB-2 (tat-) }}$ obtained from Dr. M. Feinberg (University of California, San Francisco) was made by deleting the second nucleotide in the tat initiation codon and by inserting a synthetic linker containing stop codons (18). An HIV- $1_{\mathrm{NL}} 4.3$ (tat) provirus containing a TAG codon at amino acid position 9 (glutamic acid) of the tat reading frame was constructed previously by mutagenesis at an subclone; pTS9M (19). Tat-defective HIV- $2_{\mathrm{KR} \text { (tat-) }}$ was derived from the infectious clone HIV- $2_{\mathrm{KR}}(20)$. The HIV $-2_{\mathrm{KR} \text { (tat-) }}$ mutant was engineered by deleting the first 18 nucleotides of the first coding exon of tat, including the AUG codon. HIV- $1_{\text {HXB-2 }}$ and $\mathrm{HIV}-2_{\mathrm{KR}}$ were used as controls). Infectious HIV- $2_{\mathrm{KR}}$ was generated by cotransfection with two DNA plasmids containing the $5^{\prime}$ and $3^{\prime}$ halves of the viral genome, respectively. Equal amounts of each plasmid were linearized with the restriction enzyme SacI and then ligated before transfection. The HIV-2 CAT plasmid contained HIV-2 ST LTR sequences linked to the CAT reporter gene (21). Approximately $1.4 \times$ $10^{6}$ of U937 cells were transfected with designated plasmids using the DOTAP (Boehringer Mannheim Biochemicals, Indianapolis, IN) while $1 \times 10^{6}$ cells of designated $\mathrm{T}$ cell lines were transfected with Lipofectin (GIBCO BRL, Gaithersburg, MD). $24 \mathrm{~h}$ after transfection, the designated cultures were treated with either TNF- $\alpha$ (Promega Corp.), or PMA (Sigma Chemical Co.). For CAT assays, $\sim 1.2 \times 10^{6}$ cells were transfected using DOTAP and harvested $72 \mathrm{~h}$ later. Cell extracts were prepared for analysis using the CAT-ELISA system (both from Boehringer Mannheim Biochemicals) and 1/5 of the extract was used in the assay. After the standardized assay protocol, absorbance was measured at $405 \mathrm{~nm}$ and the amount of expressed protein was calculated from a standard curve.

\section{Results}

Replication of Tat-defective viruses in the presence of TNF- $\alpha$ and PMA. To verify that tat is indeed nonfunctional in the tat mutant proviral DNA clones, we cotransfected them with an HIV-2 LTR-CAT reporter gene and measured CAT production by an ELISA assay. U937 cells, cotransfected with the reporter construct and two different HIV-1 tat-defective clones, HIV$1_{\mathrm{HXB}-2 \text { (tat) }}$ and HIV-1 $1_{\mathrm{NL}} 4.3$ (tat-), as well as HIV-2 $2_{\mathrm{KR} \text { (tat-) }}$, did not produce detectable amounts of CAT (Fig. $1 A$ ). In contrast, transfection of wild-type HIV-1 $1_{\mathrm{HXB}-2}$ and HIV-2 proviruses induced the synthesis of substantial amounts of CAT as expected. We then transfected the same proviral DNA clones into U937 cells and monitored virus replication by the antigen capture assay for capsid proteins (Fig. $1 \mathrm{~B}$ ). In cells not treated with phorbol esters, no virus expression was detected for the HIV$2_{\mathrm{KR} \text { (tat-) }}$ (lane 3 ), although virus production was rescued by providing a tat-cDNA in trans (lane 4), as previously reported $(5,22)$. Upon stimulation with PMA, virus production was enhanced for the wild-type virus; but more importantly, virus production for the HIV-2 $2_{\mathrm{KR} \text { (tat-) }}$ was now comparable to wildtype virus without stimulation (lane 5 vs. lane 1 ), and was not diminished in the presence of Ro 24-7429, a potent tat inhibitor (not shown). Tat-defective HIV-1 clones [HIV-1 $1_{\mathrm{HXB}-2 \text { (tat-) }}$ (tat-) and HIV-1 $1_{\mathrm{NL} 4.3 \text { (tat-) }}$ ] also responded to stimulation by PMA as well as TNF- $\alpha$ (Fig. $1 C$ ). Co-stimulation of cells with TNF$\alpha$ and IL- 6 further increased the amount of viral antigen production by $40 \%$ (data not shown). The synergistic effects of these cytokines on wild-type HIV-1 replication have been described previously (23).
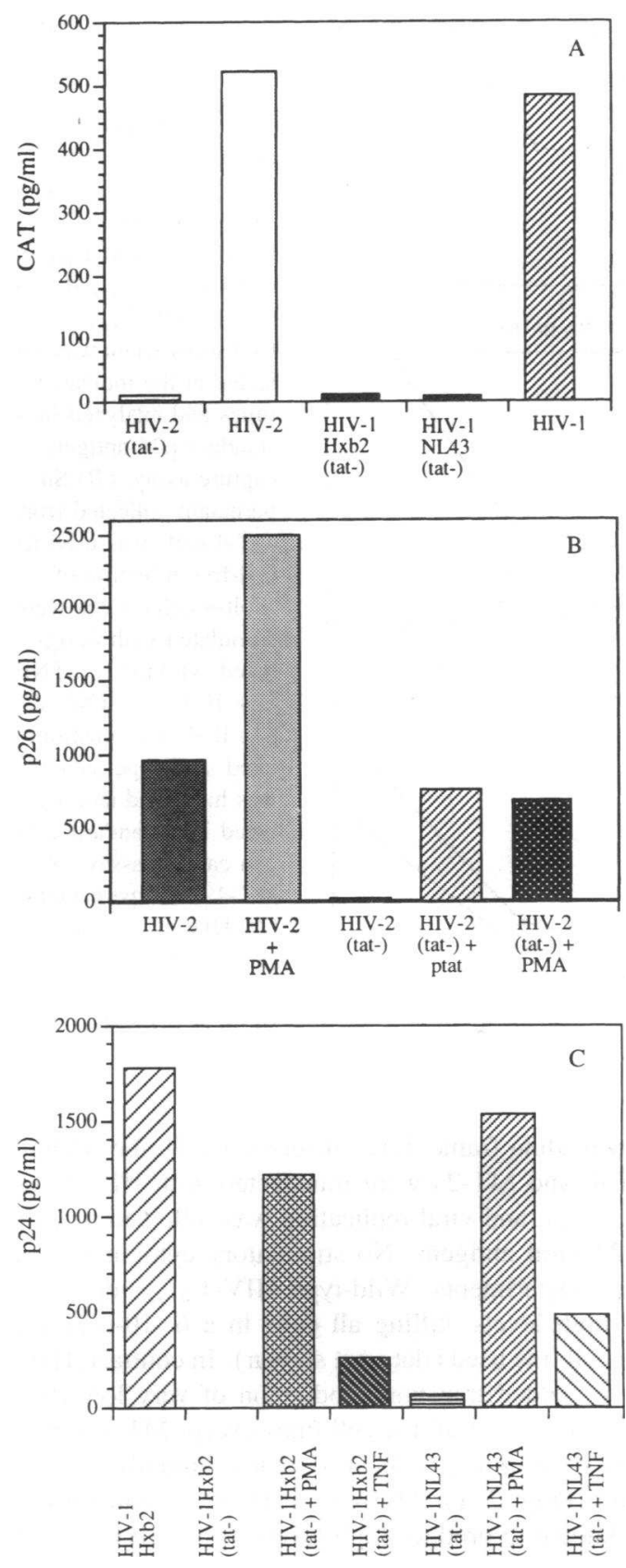

Figure 1. Replication of HIV-1 and HIV-2 tat-defective proviruses. (a) U937 cells transfected with $2 \mu \mathrm{g}$ of HIV-2 ST LTR-CAT plasmid and $2 \mu \mathrm{g}$ of different proviral clones. (b) U937 cells transfected with an

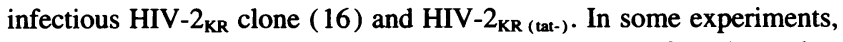
$2 \mu \mathrm{g}$ of plasmid expressing tat cDNA (p-tat) was transfected together with proviral DNA. $20 \mathrm{~h}$ after transfection, cells were stimulated with $20 \mathrm{ng} / \mathrm{ml}$ of PMA. After $2 \mathrm{~d}$, cell supernatants were harvested and analyzed in a standard p26 antigen capture assay (16). (c) U937 cells were transfected with HIV-1 $1_{\mathrm{HXB}-2}, \mathrm{HIV}-1_{\mathrm{HXB}-2 \text { (tat) }}$, and HIV-1 $1_{\mathrm{NL}-4.3 \text { (tat-) }}$ and $20 \mathrm{~h}$ later stimulated with $20 \mathrm{ng} / \mathrm{ml}$ of PMA or $10 \mathrm{ng} / \mathrm{ml} \mathrm{(80} \mathrm{U/}$ $\mathrm{ml}) \mathrm{TNF}-\alpha .2 \mathrm{~d}$ later, cell supernatants were harvested and analyzed with standard antigen capture assay (16). The results are averages of at least three separate experiments with an $\mathrm{SD}<5 \%$.

Replication and transmission of $H I V-I_{N L} 4.3$ (tat-) in various $T$ cell lines. We extended our studies with the HIV- $1_{\mathrm{NL} 4.3}$ clone, which contains functional $v p r, v p u$, and $n$ ef genes absent in the $\mathrm{HIV}-1_{\mathrm{HXB}-2}$ clone. HIV-1 $1_{\mathrm{NL} 4.3 \text { (tat-) }}$ contained a nonsense mutation 

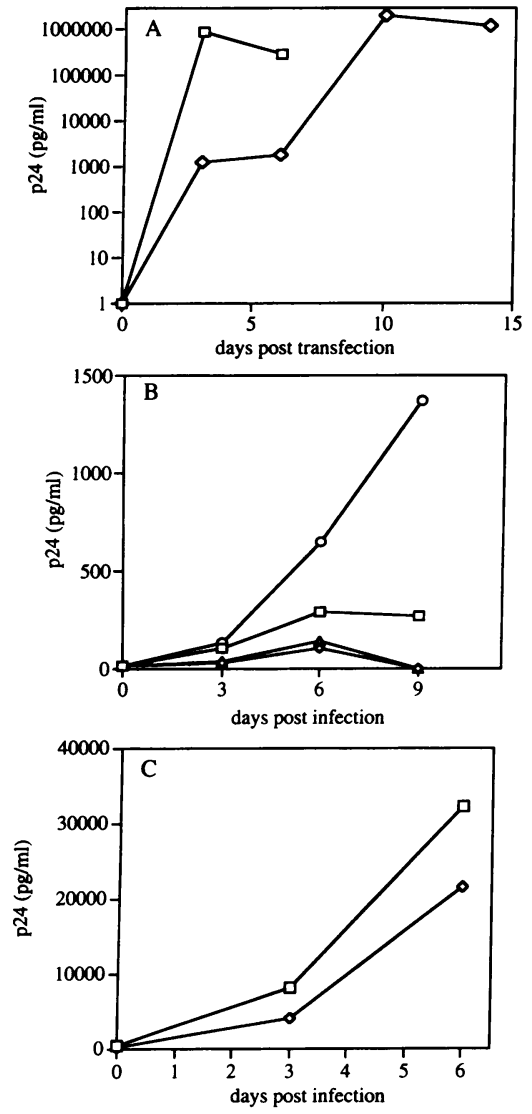

Figure 2. Replication of HIV- $1_{\text {NLA.3 }}$ and HIV. $1_{\triangle \text { tatNLA-3 }}$ viruses. $(A)$ MT4 cells were transfected with $1 \mu \mathrm{g}$ of () $\mathrm{HIV}-1_{\mathrm{NL} 4.3}$ and $1 \mu \mathrm{g}$ $(\diamond)$ of HIV- $1_{\mathrm{NL}} 4.3$ (tat-) Cell supernatant was collected at the indicated times and analyzed in a standard p24 antigen capture assay. (B) Supernatant collected from MT-4 cells was used for cell-free infection of Molt-4 cells. Cells were stimulated with designated cytokine $(O)$ TNF$\alpha+$ IL-6, () TNF- $\alpha$, $(\Delta)$ IL-6, $(\diamond)$ unstimulated, and supernatant was harvested and analyzed in a standard antigen capture assay. $(C)$ MT-4 cell supernatant of () HIV-1 $1_{\mathrm{NL} .3}$ and $1 \mu \mathrm{g}$ $(\diamond)$ of HIV- $1_{\mathrm{NL}} 4.3$ (tat) was used to infect PHAstimulated PBMC

only in the tat reading frame. Four different T cell lines (Molt3, CEM, MT-4, and MT-2) were transfected with HIV-1 $1_{\mathrm{NL}} 4.3$ and HIV-1 $1_{\mathrm{NL}} 4.3$ (tat-) , and viral replication was followed by production of p24 viral antigens. No stimulatory cytokines were added in these experiments. Wild-type HIV- $1_{\mathrm{NL}} 4.3$ replicated efficiently to high levels, killing all cells in a 6-10-d period depending on cell line used (data not shown). In contrast, HIV$1_{\mathrm{NL} 4.3 \text { (tat-) }}$ only yielded transient production of very low level virus upon transfection of all the cell lines except MT-4, which supported continuous virus replication that eventually reached wild-type levels (Fig. 2 A). MT-4 is an HTLV-1-transformed cell line also known to produce high levels of NF-kB (24). To determine whether viruses produced from the HIV- $1_{\mathrm{NL}} 4.3$ (tat-) transfected cells were infectious, and if so whether they had reverted to wild-type genotype, we infected Molt $4 / 8$ cells with virus supernatant recovered from the transfected MT-4 cells. The Molt $4 / 8$ cells were unstimulated or stimulated with IL-6, TNF- $\alpha$, or IL- $6+$ TNF- $\alpha$. Virus replication was not observed in untreated or IL-6-treated cells, but was detectable at low levels in TNF- $\alpha$-treated cells and at relatively high levels in cells treated with a combination of IL- 6 and TNF- $\alpha$. These results suggested that tat-independent virus replication occurred in the MT-4 cells in the absence of exogenous stimulation, and the recovered virus did not represent revertants of the tat mutation. It should be noted however, that revertants were generated after long time passage ( $>6 \mathrm{wk}$ ).

$T N F-\alpha$ suppresses the inhibitory effect of Ro 24-7429. Since we demonstrated that viral replication could occur in the absence of tat upon stimulation of the target cells, we wished to investigate whether the effect of a tat-specific inhibitor would be countered by the presence of physiological stimulators of
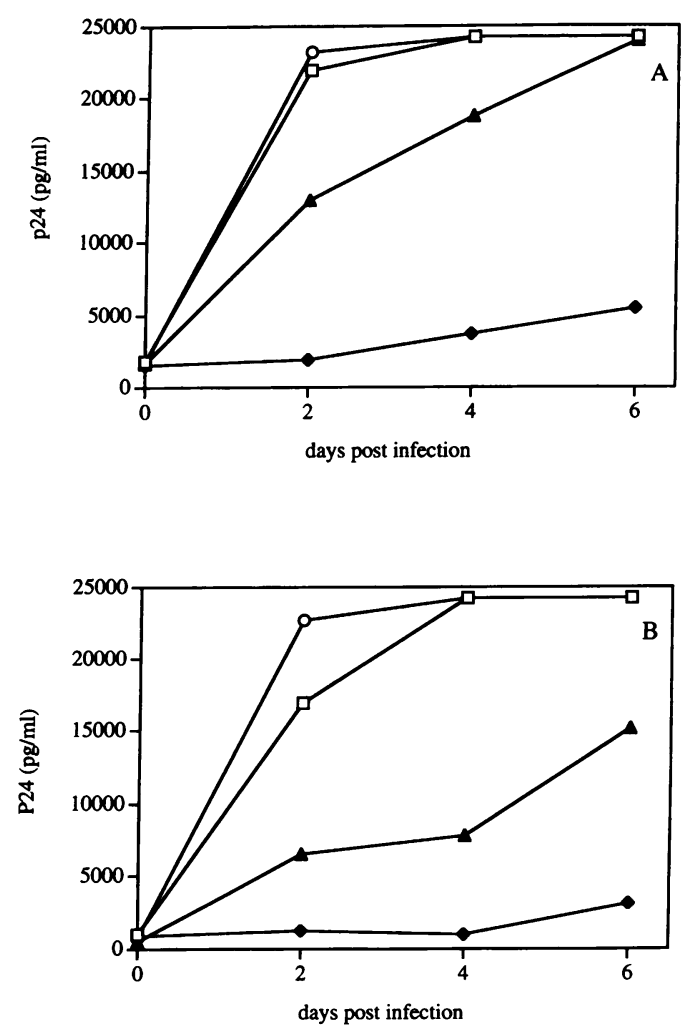

Figure 3. Suppression of antiviral effects of the Tat inhibitor, Ro-247429 , by TNF- $\alpha$. The T cell line CEM was infected with $(A)$ HIV- $1_{\text {LAI }}$ $\left(0.4=50 \%\right.$ tissue culture infectious dose $\left(\mathrm{TCID}_{50}\right) /$ cell $)$ and $(B)$ HIV$1_{\mathrm{MN}}\left(0.3=\mathrm{TCID}_{50} /\right.$ cell $)$. Ro 24-7429 was added at a concentration of $10 \mu \mathrm{M}$ and TNF- $\alpha$ was added at $10 \mathrm{ng} / \mathrm{ml} \mathrm{(80} \mathrm{U/ml)} \mathrm{to} \mathrm{some} \mathrm{cultures.}$ Cells were cultured for $1 \mathrm{wk}$ without further addition of inhibitor or TNF- $\alpha$. No significant cell toxicity was observed or has been described for this concentration ( $10 \mu \mathrm{M})$ of Ro 24-7429 (13). Supernatants were harvested from infected cultures treated with Ro 24-7429 ( $\bullet$ ), Ro 247429 and TNF- $\alpha(\Delta)$, untreated infected cells $(\square)$, and untreated infected cells stimulated with TNF- $\alpha(0)$. Supernatants were analyzed in the standard antigen capture assay $(20)$ in the designated time points. The results are averages of three separate experiments with an $\mathrm{SD}<5 \%$.

viral replication, such as TNF- $\alpha$. The replication of two HIV1 strains, HIV-1 $1_{\mathrm{MN}}$ and HIV-1 $1_{\mathrm{LAI}}$, was examined in the T cell line CEM in the presence or absence of Ro 24-7429 with or without TNF- $\alpha(10 \mathrm{ng} / \mathrm{ml})$ in the culture medium (Fig. 3). A concentration of $10 \mu \mathrm{M}$ Ro 24-7429 was used, which is 15 fold higher than the $50 \%$ inhibitory concentration of this compound in CEM cells (16). This concentration of Ro 24-7429 exhibited a potent antiviral effect during the 7-d assay period but little cellular toxicity, consistent with previous reports. However, adding TNF- $\alpha$ to the culture significantly reduced the antiviral effect of Ro 24-7429. In the absence of Ro 24-7429, TNF- $\alpha$ slightly accelerated virus replication. These results suggested that stimulation of viral replication with physiological levels of TNF- $\alpha$ can override the requirement for tat. Antiviral effect of Ro 24-7429 was also not observed with replication of HIV- $2_{\mathrm{KR} \text { (tat-) }}$ in the presence of PMA (data not shown).

To confirm that viruses recovered from TNF- $\alpha$-stimulated cultures in the presence of Ro 24-7429 were infectious, we performed titration experiments of the culture supernatant on MT- 2 cells. As can been seen in Table I, the infectious titers of HIV $-1_{\text {MN }}$ and HIV-1 $1_{\text {LAI }}$ with equal inputs of viral antigens 


\begin{tabular}{|c|c|c|c|}
\hline & $\mathrm{TCID}_{50} / \mathrm{ml}$ & & $\mathrm{TCID}_{50} / \mathrm{ml}$ \\
\hline $\mathrm{HIV}-1_{\mathrm{MN}}$ & $10^{5.5}$ & HIV-1 $1_{\text {LAI }}$ & $>10^{6.0}$ \\
\hline HIV-1 $1_{\text {MN }}+$ RO 24-7429 & $10^{2.5}$ & HIV-1 LAI $_{\text {LAI }}+$ RO 24-7429 & $10^{2.5}$ \\
\hline HIV-1 $1_{\text {MN }}+$ TNF- $\alpha$ & $>10^{6.0}$ & HIV-1 $1_{\text {LAI }}+$ TNF- $\alpha$ & $>10^{6.0}$ \\
\hline HIV-1 $1_{\text {MN }}+$ TNF- $\alpha+$ RO 24-7429 & $10^{4.5}$ & HIV- $1_{\text {LAI }}+$ TNF- $\alpha+$ RO $24-7429$ & $10^{6.0}$ \\
\hline
\end{tabular}

Culture supernatant at day 6 postinfection was used to measure infectious titer in a titration assay using MT-2 cells involving a series of progressive dilution of virus supernatant (32). The results are expressed in tissue infectious dose $\left(\mathrm{TCID}_{50}\right)$ of highest dilution of virus suspension that infects $50 \%$ of the culture as measured by visible virus-induced cytopathic effects (CPE).

were comparable in the presence or absence of Ro 24-7429 and with TNF- $\alpha$, as assayed by syncytium induction. Without TNF$\alpha$, Ro $24-7429$ suppressed virus infectivity by $\geq 10^{3} 50 \%$ tissue culture infectious dose.

\section{Discussion}

HIV-1 tat-defective proviruses have been frequently identified in the viral quasi species by direct amplification and sequencing from primary lymphocytes of patients (25). Tat-defective viruses show restricted replication in vitro, but can be passaged in tat-expressing cell lines (26). A recent study observed that two identical inactivating mutations in the first exon of tat were present in a high percentage $(50 \%)$ of proviruses in the PBMC of an HIV-1, infected asymptomatic individual (27). These results suggest that tat-defective genomes could propagate by viral replication and infectious spread in vivo.

The most important cis regulatory elements in the HIV LTRs are TAR, Sp-1, and NF-kB elements to which viral and cellular transactivators bind. Activation of viral replication with TNF- $\alpha$ occurs via induction of nuclear factor binding to the NF-kB sites, present as two tandem copies in the LTR (28). Maximal induction of viral transcription can be achieved by cooperative activation by NF-kB proteins and Tat (29). NF-kB binding sites are not required for the replication of HIV in human $\mathrm{T}$ lymphocytes as long as the three Sp-1 binding sites are retained in the LTR (24). The viruses deleted in Sp-1 sites but retaining NF-kB elements replicated efficiently in MT-4 cells and PHA-stimulated PBLs, which express high levels of NF-kB proteins, but poorly in the CEM cells unless TNF- $\alpha$ was added (30). These results suggest that NF-kB activity may functionally compensate for $\mathrm{Sp}-1$ in activating HIV replication. A recent report showed that a $T$ cell line CEMR7/neo with a stably integrated tat-defective provirus expressed low levels of virus after stimulation with TNF- $\alpha$ (31). However, they observed high levels of gag precursor Pr55gag and low levels of mature, processed proteins like p24, and concluded that TNF$\alpha$ may play a role in initiating limited early transcription of HIV-1 before tat expression, but could not replace the potent transcriptional and posttranscriptional effects of tat for efficient virus expression. Our data, in contrast, showed that tat-defective viruses can replicate to near wild-type levels in the presence of TNF- $\alpha$ or PMA after transient transfection into U937 cells, or in MT-4 cells without stimulation. It is noteworthy that virus replication in MT-4 was previously found to be refractory to the tat antagonist (32). Since both MT-2 and MT-4 cell lines are transformed by HTLV-1 and express the Tax protein, the preferential replication of tat-defective virus in MT-4, but not MT- 2 cells could not be accounted for solely by stimulation of
NF-kB by Tax. Additional cellular factors (including high levels of NF-kB) expressed in MT-4 cells must contribute to the rescue of $\mathrm{HIV}-1_{\mathrm{NL}} 4.3$ (tat-) virus.

Elevated production of cytokines may be an important component of the immunopathogenesis and disease progression of HIV infection (33-35). TNF- $\alpha$ and other inflammatory cytokines have been reported to be present at elevated levels in the plasma or cerebrospinal fluid of HIV-infected individuals (10, $36,37)$. Peripheral blood lymphocytes and monocytes from infected patients may also spontaneously produce high levels of TNF- $\alpha(12,13)$. Furthermore, increased amounts of transmembrane TNF- $\alpha$ have been noted on T and B cells $(35,38)$ and have been implicated in the polyclonal $\mathrm{B}$ cell activation of these patients (39). The elevated levels of cytokines (TNF- $\alpha$, IL-1, IL-6), in addition to exerting systemic effects on the host (fever, cachexia) could also contribute to activating virus production, including production from tat-defective genomes.

Because of prior evidence for the essential role of tat in HIV replication in vitro, many antiviral strategies are aimed at inhibiting tat function. Our results indicate that activating the virus through the NF-kB pathway in the presence of a tat inhibitor can significantly rescue viral replication. Therefore, such inhibitors may not be effective in vivo since immune activation and cytokine induction are common occurrences in infected individuals. This may explain in part the discouraging results of a phase clinical trial with this same tat antagonist Ro 247429 (40). The HIV LTR contains multiple protein-binding sites that have variable importance in different cell types and may functionally complement each other. Therefore, therapy aiming to inhibit viral transcription should include inhibitors of both tat transactivation and transactivation through NF-kB or other cellular factors. Two compounds through to inhibit HIV replication in vitro through inhibition of the NF-kB pathway are pentoxyfylline $(41,42)$ and thalidomide $(43)$. Pentoxyfylline inhibits NF-kB interactions with its response elements (42), while thalidomide inhibits TNF- $\alpha$ mRNA expression (43). Additionally, selective blocking of other cytokines could have important implications in treatment of HIV disease.

\section{Acknowledgments}

We would like to thank Drs. D. Looney and E. Poeschla for critical comments and N. Riggs for technical assistance.

This work was supported by grants (National Institutes of Health RO1 AI-29889-03 to F. and AI-27670, AI-29164, AI-30457 and Research Center for AIDS and HIV infection of the San Diego Veterans Affairs Medical Center to D. D. Richman). L. Luznik is a recipient of an International Postdoctoral Research Fellowship, Fogarty International Center, National Institutes of Health. J. C. Guatelli was supported by a career development award from the Department of Veterans Affairs. 


\section{References}

1. Steffy, K., and F. Wong-Staal. 1991. Genetic regulation of human immunodeficiency virus. Microbiol. Rev. 55:193-205.

2. Cullen, B. R. 1993. Does HIV-1 tat induce a change in viral initiation rights? Cell. 73:417-420.

3. Fisher, A. G., M. B. Feinberg, S. F. Joseph, M. E. Harper, L. M. Marselle, G. Reyes, M. A. Gonda, A. Aldovini, C. Debouk, R. C. Gallo, and F. WongStaal. 1986. The trans-activator gene of HTLV-III is essential for virus replication. Nature (Lond.). 320:367-371.

4. Dayton, A. I., J. G. Sodorski, C. A. Rosen, W. C. Goh, and W. A. Haseltine. 1986. The trans-activator gene of the human T cell lymphotropic virus type III is required for replication. Cell. 44:941-947.

5. Sadaie, R. M., J. Rappaport, T. Benter, S. F. Joseph, R. Willis, and F. Wong-Staal. 1988. Missense mutations in an infectious human immunodeficiency viral genome: functional mapping of tat and indentification of the rev splice acceptor. Proc. Natl. Acad. Sci. USA. 85:9224-9229.

6. Harrich, D., J. Garcia, R. Mitsuyasu, and R. Gaynor. 1990. TAR independent activation of the human immunodeficiency virus in phorbol ester stimulated T lymphocytes. EMBO (Eur. Mol. Biol. Organ.) J. 10:4417-4423.

7. Jones, K. A., J. T. Kadonga, P. A. Luciw, and R. Tijan. 1986. Activation of the AIDS retrovirus promoter by the cellular transcription factor Sp1. Science (Wash. DC) 232:755-759.

8. Nabel, G. A., and D. Baltimore. 1987. An inducible transcription factor activates expression of human immunodeficiency virus in T cells. Nature (Lond.) 326:711-713.

9. Osborn, L., S. Kunkel, and G. Nabel. 1989. Tumor necrosis factor- $\alpha$ and interleukin 1 stimulate the human immunodeficiency virus enhancer by activation of the nuclear factor kB. Proc. Natl. Acad. Sci. USA. 86:2336-2340.

10. Reddy, M. M., S. J. Sorrel, M. Lange, and J. Grieco. 1988. Tumor necrosis factor and HIV p24 antigen levels in serum of HIV-infected populations. Aids (Phila.) 1:436-440.

11. Mintz, M., R. Rappaport, J. M. Oleske, E. M. Connor, M. R. Koenigsberger, T. Denny, and L. G. Epstein. 1989. Elevated serum levels of tumor necrosis factor are associated with progressive encephalopathy in children with acquired immunodeficiency syndrome. AJDC (Am. J. Dis. Child.). 143:771-774.

12. Poli, G., and A. S. Fauci. 1992. The effect of cytokines and pharmacologic agents on chronic HIV infection. Aids Res. Hum. Retroviruses. 8:191-197.

13. Wright, S. C., A. Jewett, R. Mitsuyasu, and B. Bonavida. 1988. Spontaneous cytotoxicity and tumor necrosis factor production by peripheral blood monocytes from AIDS patients. J. Immunol. 141:99-104.

14. Sullenger, B. A., H. F. Gallardo, G. E. Ungers, and E. Gilboa. 1990. Overexpression of TAR sequences renders cells resistant to human immunodeficiency virus replication. Cell. 63:601-608

15. Hsu M.-C., A. D. Schutt, M. Holly, L. W. Slice, M. I. Sherman, D. D. Richman, M.-J. Potash, and D. J. Volsky. 1991. Inhibition of HIV replication in acute and chronic infections in vitro by a tat antagonist. Science (Wash. DC). 254:1799-254.

16. Hsu M.-C., U. Dhingre, J. V. Earley, M. Holly, D. Keith, C. M. Nalin, A. R. Richou, A. D. Schutt, S. Y. Tam, M. J. Potash, D. J. Volsky, and D. D. Richman. 1993. Inhibition of type 1 human immunodeficiency virus replication by a tat antagonist to which the virus remains sensitive after prolonged exposure in vitro. Proc. Natl. Acad. Sci. USA. 90:6395-6399.

17. Braddock, M., P. Cannon, M. Muckenthaler, A. J. Kingsman, and S. M. Kingsman. 1994. Inhibition of human immunodeficiency virus type-1 tat-dependent activation of translation in Xenopus oocytes by the benzodiazepine Ro 247429 requires trans-activation response element loop sequences. J. Virol. 68:2533.

18. Feinberg, M. B., D. Baltimore, and A. D. Frankel. 1991. The role of tat in the human immunodeficiency virus life cycle indicates a primary effect on transcriptional elongation. Proc. Natl. Acad. Sci. USA. 88:4045-4049.

19. Riggs, N. L., S. J. Little, D. D. Richman, and J. C. Guatelli. 1994. Biological importance and cooperativity of HIV-1 regulatory gene splice acceptors. Virology. 202:264-271.

20. Talbott, R., G. Kraus, D. Looney, and F. Wong-Staal. 1993. Mapping the determinants of human immunodeficiency virus type-2 for infectivity, replication efficiency and cythopathicity. Proc. Natl. Acad. Sci. USA. 90:4226-4230.

21. Kumar, P., H. Hui, J. C. Kappes, B. S. Haggarty, J. A. Hoggie, S. K Arya, G. M. Shaw, and B. H. Hahn. 1990. Molecular characterization of an attenuated isolate of HIV-2. J. Virology. 64:890-901.

22. Chen, H., T. J. Boyle, M. H. Malim, B. R. Cullen, and H. K. Lyerly. 1992. Derivation of a biologically contained replication system for human immunodeficiency virus type-1. Proc. Natl. Acad. Sci. USA. 89:7678-7682.

23. Poli, G., P. Bressler, A. Kinter, E. Duh, W. C. Timmer, A. Rabson,
J. S. Justement, S. Stanley, and A. S. Fauci. 1990. Interleukin 6 induces human immunodeficiency virus expression in infected monocytic cells alone and in synergy with tumor necrosis factor $\alpha$ by transcriptional and post-transcriptional mechanisms. J. Exp. Med. 172:151-158.

24. Leonard J., C. Parrott, A. J. Buckler-White, W. Turner, E. K. Ross, M. A. Martin, and A. B. Rabson. 1989. The NF-kB binding sites in the human immunodeficiency virus type 1 long terminal repeat are not required for virus infectivity. J. Virol. 63:4919-4924.

25. Meyerhans A., R. Cheynier, J. Albert, M. Seth, S. Kwok, J. Sninsky, L. Morfeld-Manson, B. Asjo, and S. Wain-Hobson. 1989. Temporal fluctuations in HIV quasispecies in vivo are not reflected by sequential HIV isolation. Cell. 58:901-910.

26. Asjo B., J. Albert, F. Chiodi, and E. M. Fenyo. 1988. Improved tissue culture technique for production of poorly replicating human immunodeficiency virus strains. J. Virol. Methods. 19:191-196.

27. Sabino, E., C. Cheng-Mayer, and A. Mayer. 1993. An individual with a high prevalence of a tat-defective provirus in peripheral blood. Aids Res. Hum. Retroviruses. 9:1265-1268.

28. Duh, E. J., W. J. Maury, T. M. Folks, A. S. Fauci, and A. B. Rabson. 1989. Tumor necrosis factor- $\alpha$ activates human immunodeficiency virus type through induction of nuclear factor binding to the NF-kB sites in the long termina repeat. Proc. Natl. Acad. Sci. USA. 86:5974-5978.

29. Liu, J. L., N. D. Perkins, R. M. Schmid, and G. J. Nabel. 1992. Specific NF-kB subunits act in concert with tat to stimulate human immunodeficiency virus type 1 transcription. J. Virol. 66:3883-3887.

30. Parrot, C., T. Seidner, E. Duh, J. Leonard, T. S. Theodore, A. BucklerWhite, M. A. Martin, and A. B. Rabson. 1991. Variable role of the long termina repeat. Spl-binding sites in human immunodeficiency virus replication in T lymphocytes. J. Virol. 65:1414-1419.

31. Popik, W., and P. M. Pitha. 1993. Role of tumor necrosis factor $-\alpha$ in activation and replication of the tat-defective human immunodeficiency virus type 1. J. Virol. 67:1094-1099.

32. Witvrouw, M., R. Pauwels, A.-M. Vandame, D. Schols, D. Reymen, N. Yamamoto, J. Desmyter, and E. De Clercq. 1992. Cell type-specific anti-human immunodeficiency virus type 1 activity of the transactivation inhibitor Ro 5-3335. Antimicrob. Agents Chemother. 36:2628-2633.

33. Molina, J.-M., D. T. Scadden, R. Byrn, C. A. Dinarello, and J. E. Groopman. 1989. Production of tumor necrosis factor and interleukin $\beta$ by monocytic cells infected with human immunodeficiency virus. J. Clin. Invest. 84:733-737.

34. Merrill J. E., Y. Koyanagi, and I. S. Y. Chen. 1989. Interleukin-1 and tumor necrosis factor- $\alpha$ can be induced from mononuclear phagocytes by human immunodeficiency virus type 1 binding to the CD4 receptor. J. Virol. 63:44044408.

35. Nakajima, K., O. Martinez-Maza, T. Hirano, C. Breen, P. G. Nishanian, S. Salazar-Gonzales, J. L. Fahey, and T. Kishimoto. 1989. Induction of IL-6 (B cell stimulatory factor-2/IFN- $\beta 2$ ) production by HIV. J. Immunol. 142:531-536.

36. Breen, A. C., A. R. Rezai, K. Nakajima, G. N. Beall, R. T. Mitsuyasu, T. Hirano, T. Kishimoto, and O. Martinez-Maza. 1990. Infection with HIV is associated with elevated IL-6 levels and production. J. Immunol. 144:480-484.

37. Gallo, P., K. Frei, C. Rordford, J. Lazdins, B. Tavolato, and A. Fontana. 1989. Human immunodeficiency virus type 1 (HIV-1) infection of the central nervous system: an evaluation of cytokines in cerebrospinal fluid. J. Neuroimmunol. 23:109-116.

38. Liu, A. Y., E. P. Miskovsky, P. E. Stanhope, and R. F. Siliciano. 1992. Production of transmembrane and secreted forms of tumor necrosis factor (TNF$\alpha$ ) by HIV-1 specific CD4+ cytotoxic T lymphocyte clones. Evidence for a TNF$\alpha$ independent cytolytic mechanism. J. Immunol. 12:3789-398.

39. Macchia, D., F. Almerigogna, P. Parronichi, A. Ravina, E. Maggi, and S. Romagnani. 1993. Membrane tumor necrosis factor is involved in the polyclonal B-cell activation induction by HIV-infected human T cells. Nature (Lond.). 363:464-466.

40. Haubrich, R. H., and the ACTG 213 team. 1993. Randomized study of safety, tolerance, pharmacokineticks, and activity of oral Ro 24-7429 (Tat antagonist) in patients with HIV infection. Ninth International Conference on AIDS. 64 (Abstr. WS-B26-5).

41. Fazely, F., B. J. Dezube, J. Allen-Ryan, A. B. Pardee, and R. M. Ruprecht. 1991. Pentoxifylline (trental) decrease the replication of the human immunodeficiency virus type 1 in human peripheral blood mononuclear cells and in cultured T cells. Blood. 77:1653-1656.

42. Biswas, D. K., B. J. Dezube, C. M. Ahlers, and A. B. Pardee. 1993 Pentoxifylline inhibits HIV-1 LTR driven gene expression by blocking NF-kB Action. Aids Res. Hum. Retroviruses. 6:778-786.

43. Makonkawkeyoon, S., R. N. R. Limson-Pobre, A. L. Moreira, V. Schauf, and G. Kaplan. 1993. Thalidomide inhibits the replication of human immunodeficiency virus type 1. Proc. Natl. Acad. Sci. USA. 90:5974-5978. 